\title{
The role of Linear Pottery houses in the process of neolithisation
}

\author{
Ivan Pavlů \\ Department of Archaeology, University of Hradec Králové, CZ \\ ipavlu@gmail.com
}

\begin{abstract}
A Linear Pottery settlement represents on a certain scale a symbiosis of different socio-economic groups of inhabitants in one given space. The role and status of artefacts can be described according to individual types of houses. Stockbreeding is typical for large houses, while small houses manifest hunting as well as breeding. Three-part houses are the most significant buildings as the artefact assemblages display prestigious social roles. The assemblages in the single-part houses suggest household activities.
\end{abstract}

IZVLEČEK - Naselbina linearno-trakaste keramike predstavlja v določeni meri simbiozo med različnimi družbeno-gospodarskimi skupinami prebivalcev $v$ danem prostoru. Vlogo in status najdb lahko opisujemo glede na posamezne tipe hiš. živinoreja je značilna za večje hiše, medtem ko sta za manjše hiše značilna tako lov kot živinoreja. Tridelne hiše so najbolj pomembne stavbe v naselbini in njihovo prestižno družbeno vlogo lahko prepoznamo na podlagi artefaktnih zbirov. Na drugi strani pa artefaktni zbiri iz enodelnih hiš kažejo na bolj gospodinjske aktivnosti.

KEY WORDS - Neolithic; Linear Pottery; ceramics; houses; society

\section{Typology of houses}

We have only indirect evidence about the inhabitants of Neolithic settlements. We consider the ground plans of houses known since the 1930s as among the most important. The latest overview of Neolithic houses in Czech literature shows that the number of excavated buildings has been increasing recently in Bohemia as well as Moravia and other regions (Podborsky 2011). Recent years have seen a thorough discussion of house typology; however, current propositions are still considered the most feasible explanation of the archaeologically welldocumented situation of Neolithic houses (Lenneis 2000). The views of Pieter J. R. Modderman, who contributed significantly to the typology of Neolithic houses, serves best to illustrate their genesis and development. In the 1950s and 1960s, when Dutch findings in Limburg were published, Modderman defined three basic types of houses and several subtypes. Although his original objective was to use the typological studies to create a chronology, his basic typology remains usable to this day. A simpler typology was introduced later by Anick Coudart (1998). In the publication of large-scale excavations in the Elsoo and Stein localities in 1970, Modderman (1970.109-112) also offered an interpretation of individual parts of houses.

The significance of each of the three parts of the houses built in the earliest period of Linear Pottery was addressed in great detail by Harald Stäuble (2005.191-198). Above all, he disputes the possibility that thick inner posts of the houses could have supported a second storey, claiming that such a structure would be unstable. He also speculates that postholes connected into trenches suggest a possible lengthwise division of the interior which would allow for stabling of animals. However, he claims that the resulting space was a kind of roofed 'porch', a space open to the south which hosted various outdoor activities (Stäuble 2005.194). He also criticises 
previous arguments that claim that the solid structure of the northern part of the house was a 'bedroom'. He refuses the notion that this part was a stall, citing inconclusive data from a phosphate analysis. For him, the northern part of the house was used by the occupants for storing valuables or supplies, or for cult purposes. The differences in the sizes of the northern part in different houses reflect the extent to which the occupants were willing to exhibit their possessions (Stäuble 2005.198). Coudart had already used the variability of the size of northern house parts to modify her own typology. She retained the division into three house types, but defined it only by the number of constructional triads in the said part of the house. Furthermore, she denies that single-part houses were used throughout the whole Linear Pottery area (Coudart 1998.57, note 9).

\section{Animal bones found in houses}

One of the most extensive analyses of the distribution of animal bones in a Neolithic settlement was conducted in the locality of Cuiry-lès-Chaudardes (CCF) in the western border region of the European Linear Pottery area (Hachem 2011). The significance of the distribution of animal bone remains in the settlement as a whole is surpassed by the significance of their correspondence to different types of houses. The relation between the houses and different species of animal in the CCF locality is characterised by their quantitative ratio in the pits of individual houses. We can distinguish the main animal species and complementary ones. Livestock - cattle, as well as sheep and goat - predominates in the larger houses (constituting almost $90 \%$ of the contents of the pits). Complementary to these domestic animals, game animals are present, especially aurochs, and red and roe deer. More than $23 \%$ of hunted animals are found in small houses, wild boar being the most frequent. The complementary species in small houses is domesticated pig (Hachem 2011.224225 ). In some smaller and larger houses, the predominant animals are game (80\%), either deer combined with pigs and cows, or aurochs combined with sheep and goat. The variety of animal species found in different types of houses shows that the primary source of family subsistence, at least regarding meat consumption, varied widely.

The correspondence of different animal species to different types of houses is comparable at the Bylany- part 1 (BY1) settlement, although the ratio of animal bone remains at Bylany is much less favou- rable than at CCF (Kovačiková et al. 2012). We can certainly state that in Bylany, game animals also relate mainly to small houses with a single area inside, while domesticated livestock prevails in large houses divided into three areas (Fig. 1). However, these relations do not mean that a specific species is exclusive to a specific type of house. Instead, we can agree with the interpretation of the CCF situation, where the occupants of small and large houses differed in their meat preferences, regardless of the fact that they had access to all the species at the time ( $\mathrm{Ha}$ chem 2011.235). Since the animal bone remains at the Bylany settlement are not very numerous and the bones of hunted animals are scarce, it was impossible to identify any specific part of the settlement with a higher concentration of houses where hunted animals were predominant (Peške et al. 1998).

\section{Pottery categories in the houses}

Therefore, in Bylany, the relation between species and house type has no correspondence in the spatial division of the settlement, which leads us to another question (Modderman 1986; 1988). Is it possible that certain other artefacts are also significantly linked to the three different house types? We have studied the main categories of artefacts, especially their previously defined functional types, and a relation to different house types was indeed established. In pottery, these were: functional sets of containers, types of ornamentation and basic techniques of line-

\section{Correspondence Plot}

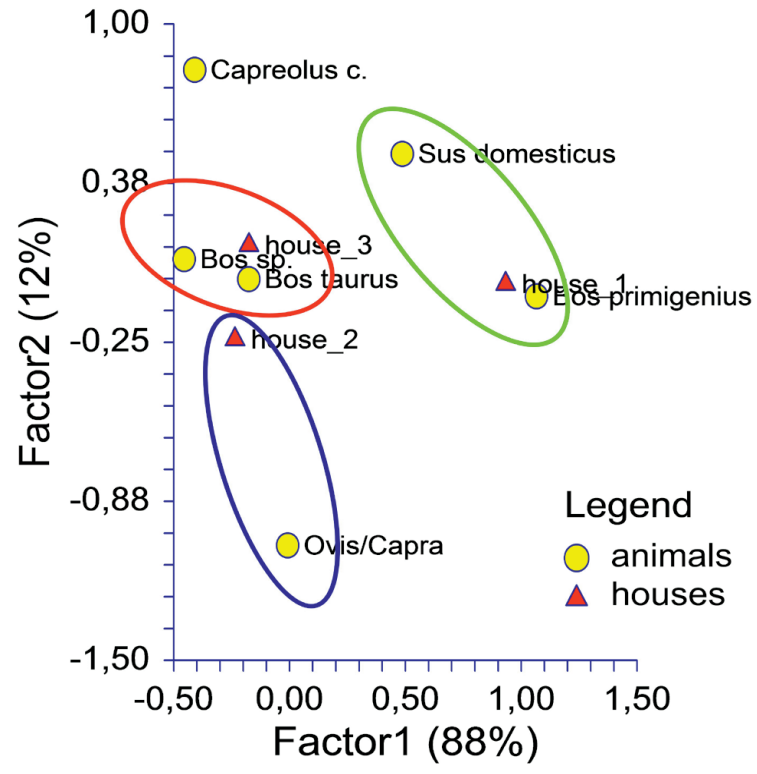

Fig. 1. Bylany, correspondence analysis of animal bones in houses: House 1 - single-part house; House 2 - two-part house; House 3 - three-part house. 
ar decoration. It is necessary to stress that in some cases the relation to a specific house type was not interpreted unequivocally, especially in the category of ceramic technology.

The first category of pottery, with which we studied the relation of artefacts to house types, were the functional sets of containers (SHASI - shape and size) determined by the form and diameter of the mouth (Pavlu 2000.119). In both cases, the resulting two factors were established by the contrast between set number three, consisting of containers for serving food, and set number five, of large storage vessels (Fig. 2). The former is linked to singlepart houses, while the latter relates to three-part houses. Two-part houses can be conclusively connected only to the small F11-type container. The remaining three functional sets of container (Types 1,2, and 4) cannot be ascribed to any kind of house. However, the third set was surprisingly concentrated around single-part houses.

We also studied the relation between different types of house and the ornamentation of containers by way of analysing the main categories of ornamentation: linear decorated (LO), relief decorated (PO), technically decorated (TO), and undecorated cera-

\section{Correspondence Plot}

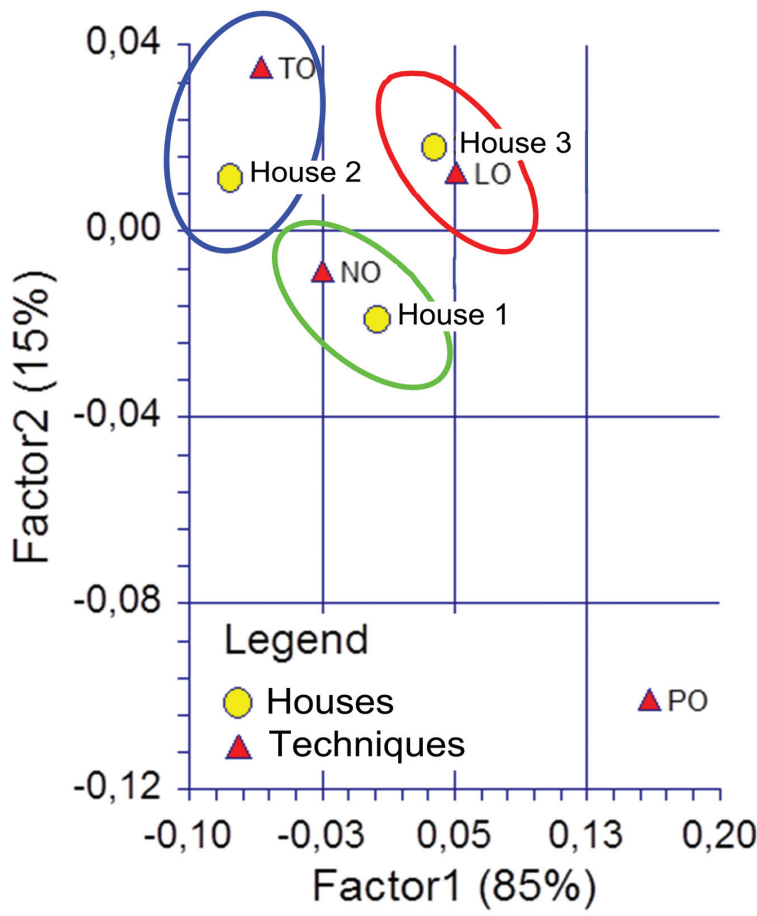

Fig. 3. Bylany, correspondence analysis of the main types of pottery ornamentation in houses: LO - linear; PO - relief; TO - technical; NO - undecorated.

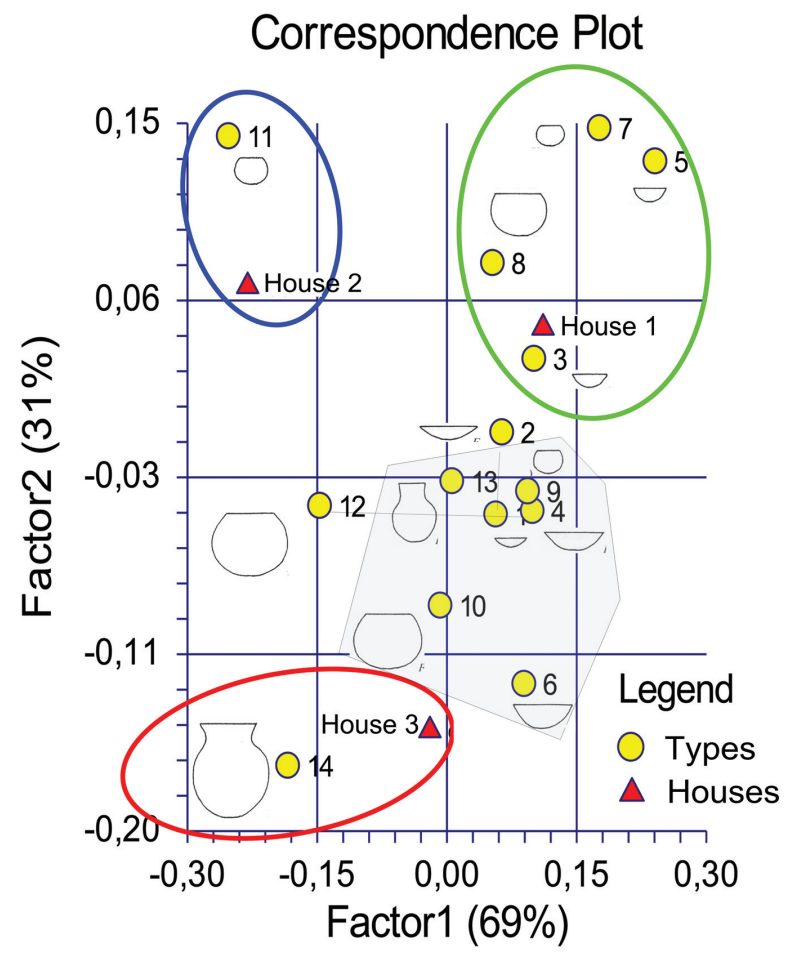

Fig. 2. Bylany, correspondence analysis of functional types of containers in houses: Types 1-14 (functional types according to Pavlů 2000.Fig. 4.5. 4.c).

mics (NO). In the first factor, there is an opposition between relief and technical decoration; in the second factor the opposition is between technical and relief decoration (Fig. 3). Linear decoration is closely related to two-part houses, while undecorated pottery predominates in single-part houses. Bipartite houses can be linked to undecorated pottery, as well as pottery with technical ornamentation. Relief decoration is not related to any specific type of house.

Another category in which we studied the relation to specific house types was the technique of decoration. The results rendered by correspondence analysis enabled us to interpret the first factor as chronological and to some extent geographic, since early stepladders are separated from negative numbers on the factor score (Fig. 4). The second factor is also partially chronological in negative numbers, where we encountered the earliest three-line ribbon, while in positive numbers it tends to be structural, dividing filled band from music-note decoration technique.

\section{Social significance of artefacts according to house type}

The role of artefacts can be described according to individual types based on the results of the various artefacts analyses. At Neolithic settlements, three-part 
houses are the most significant buildings. This is demonstrated by their correspondence to rim fragments and close relation to pottery with linear decoration. The inhabitants of three-part houses preferred containers designed for storage, meaning that pottery was not only used for immediate everyday needs, but also for long-term use. We assume that these long-term purposes were related to a close group of inhabitants of a given house as well as to all the people at the settlement. If filled band was preferred, linear ornamentation represents the most progressive ornamentation technique within the Czech region. Stone tools demonstrate the specific functions of these houses: tools for sharpening belong to prestigious households; cutting tools (such as sickle blades and regular scrapers on medium sized blades) were used in ordinary houses for farming and food processing. In summary, apart from utility functions, artefacts related to three-part houses played important social roles corresponding to the prestige of the occupants of given houses. We can therefore conclude that the occupants of threepart houses had the specific role and status in the settlement. This treatment of artefacts corresponds well with existing interpretations of these buildings, which were based primarily on the precision of their construction (Modderman 1970.112; Van de Velde 2007).

The results obtained by studying the situation of single-part houses offer a completely different picture. Based on the prevailing amount of wall fragments and fragments of undecorated containers, we assume that pottery played no particular role in these houses. When it comes to the function of pottery, its usage in small houses was standard. The only indicator of specific food composition and role of pottery is the connection to the vessels of liquid food consumption, which is a certain metaphorical interpretation of its function. Decorated vessels were less important and vessels with simple engraving technique were preferred, therefore we assume that pottery played a secondary role for the inhabitants of single-part houses. The conservative decorative technique of engraved lines can be compared to the techniques of the earliest level of Linear Pottery from which it originated during the classic period of the Linear Pottery culture. Stone tools manifest preferred activities: wood working, manufacturing of wooden objects; arrows can be connected to hunting, and knives to food processing. Hand-stones were not used often, and only fragments of grind-stones were found in single-part houses, which shows that vegetable and plant processing was not significant.

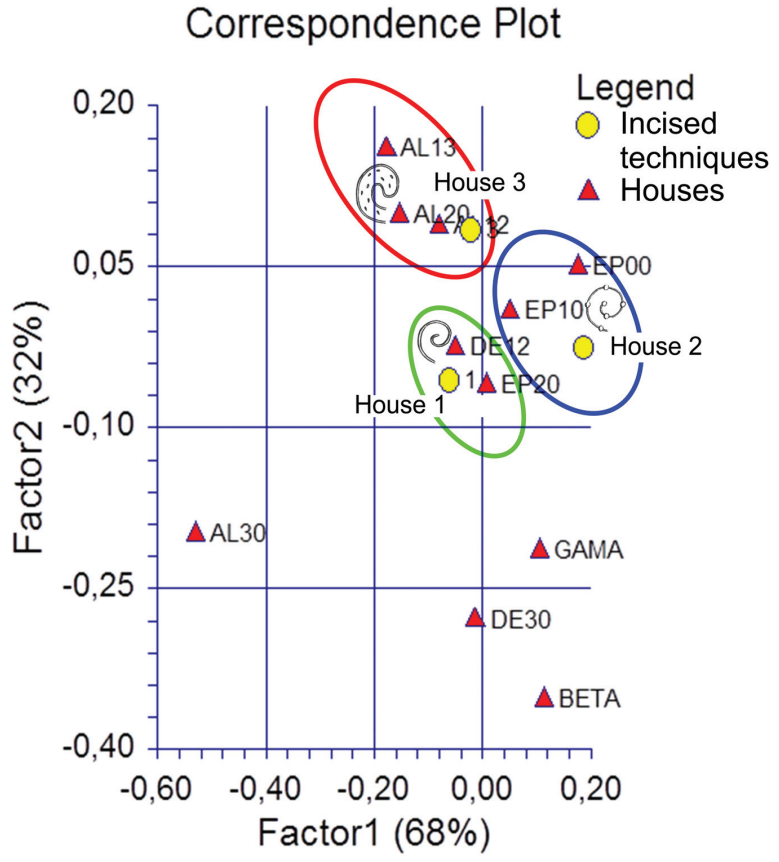

Fig. 4. Bylany, correspondence analysis of the techniques of linear decoration in houses: $A L$ - filled line; $\mathrm{EP}$ - music-note decoration; $\mathrm{DE}$ - simple engraved line.

This implies that the occupants of single-part houses were of different high-ranking in society as the occupants of three-part houses.

The connection to artefacts is not so pronounced in two-part houses as in the two previous types. We would have expected the role of artefacts and the resulting status of occupants of bipartite houses to lie somewhere between three-part and single-part houses. However, pottery in two-part houses was less significant, similarly to the situation in singlepart houses, as observed in the predominance of wall fragments as well as in the decoration of the pottery. Vessels from the bipartite houses were also technically ornamented, especially on rough cooking vessels or storage containers. The only functional type of a small bomb-shaped container does not represent a significant link with the role of pottery. On the other hand, the connection with the musicnote decoration is very significant in its role of continuous ornamentation techniques, with an increasing tendency to subsequent socio-historical changes. In the last period of Linear Pottery, the leading line of the notes changes into a punctured line, a stylistic manifestation of the principal change in decoration leading to the Stroke-ornamented ware culture. Usage of stone tools is standard, the functions being woodworking and the manufacture of cutting tools and grind stones. The social role of these stone tools is not very pronounced; however, it shows certain 
particularities. The link to drilled celts is noteworthy, but not massively observed in relation to bipartite houses. This can be indicative of a certain degree of individual prestige of some inhabitants of the settlement. We can conclude that two-part houses had a specific role in the society of Neolithic settlements.

\section{Social role and status of occupants according to house type}

The analysis of animal bones at the BY1 settlement leads to similar conclusions, although they are not identical. Stockbreeding (with cattle being predominant) is typical of large houses, while small houses show evidence of hunting as well as animal husbandry (especially of sheep and goats). However, the occupants of houses with a northern part tended to keep pigs rather than cattle. The differentiation in means of subsistence is also similar, although as observed in the small amount of bones preserved, hunting was not of great significance. It is nevertheless important that we are able to document different means of subsistence as well as different farming methods and agricultural activities in one locality over a longer period. We can state that we are dealing not only with different types of farmers, but also hunters to a certain extent. We assume that the absence of a southern part in two types of houses indicates less or no participation of their occupants in the cultivation of vegetables and plants. This hypothesis would explain the different roles of certain artefacts found in bipartite and single-part houses. All the evidence therefore points to the existence of a variety of agricultural activities within one Neolithic settlement.

Lamys Hachem (2011), describing the processing of animal bone remains at the CCF locality, did not settle only for an economic hypothesis. She added a socio-ideological hypothesis based on the symbolic role of hunting. She explains the segmentation of village society into three parts by the differences between families and their different relations in the organisation of clans. Their affiliation was determined by their different origins. Different myths and animal symbolism are connected to different origins, which enables us to infer the origins of different groups of inhabitants (Hachem 2011.207). This symbolism is projected into different forms of subsistence, as well as the division of the space that the inhabitants occupy within the settlement. However, it is impossible to apply these hypotheses unambiguously to the situation at the BY1 settlement, be- cause its archaeological structure is different. It is less pronounced in terms of spatial organisation, and the preserved animal bone remains are less abundant. We therefore believe that it is necessary to consider Neolithic society as highly differentiated in terms of its economy as well as ideology. The differences between the inhabitants of one settlement or one area ought to be assessed individually with regard to the condition of archaeological evidence.

Modderman stressed the social role of Neolithic houses as early as 1970, although his interpretation was not a very detailed. He considered that the quantities of the three types remained unchanged in the Early to Late period of Linear Pottery in Limburg, with the exception of the house type $1 \mathrm{~b}$ with a gouge along the walls in the northern section of the building's circumference. The numbers of houses declined in the Late Neolithic. The steady number of buildings with a gouge around the whole perimeter (around $10 \%$ ) leads him to establish the social need for houses of this type (Modderman 1970.112). The numbers of small houses and houses with a northern section increased only slightly in the Late Linear Pottery period.

With the analysis of individual categories of artefacts we can distinguish between two levels of social status of occupants of different house types. The occupants of three-part houses had the highest status, having a fully Neolithised economy based on animal husbandry and cereal farming. Intensive gardening (Boggard 2004.164) was probably situated on the southern side of the house, which in most cases is free of embedded objects. The occupants were bearers of a socio-historical trend which only later demonstrated the advantages of agriculture, since in the first centuries, when agricultural techniques had not yet stabilised, early types of agriculture might not have been fully self-supporting in some circumstances. Animals were kept on the northern side of the house. In some cases, we have evidence of a separate enclosure (BY1, house 912). The northern side of the house might not have served as an animal enclosure, but it was possibly used in winter to shelter smaller animals such as sheep or pigs.

The preferred role is attributed to the most solid constructed large houses built in Neolithic settlements. In the Netherlands, one such house always occurs among all the other contemporary houses, which shows its uniqueness (Van de Velde 2007. 226). In the Bylany settlement, we identified simi- 
larly important houses in the earliest (house 2197) and later periods (houses 306, 41, 912, etc.). Their occurrence depended on the number of contemporary houses; they probably constituted a necessary organisational element at times when free self-government was not enough (Pavli 2000.254).

In Bylany, single-part houses are the counterpart of three-part houses, and belonged to families of relatively particular social status. A house with one central residential space could be used only limited stockbreeding and would have no land for cultivation. Hunting would remain the primary means of subsistence for its occupants, with the possible addition of gathering and/or a small herd of sheep or goats kept outdoors. The inhabitants of such houses were not forced to remain permanently at the settlement; when the climate was favourable, they were able to live outside for some parts of the year and return only for the winter. However, they could also provide certain food supplies for other members of the society and thus ensure an alternative source of subsistence. They constituted a conservative element within the settlement, but an element which was a bearer of the tradition of a given place and settlement region.

In the Bylany settlement, artefacts from the bipartite houses bore signs of specific treatment. We could argue that the absence of the southern section of the house means its occupants did not engage in farming or gardening. The walls of the northern part of the house were often reinforced. The corresponding animal bones show that the occupants of bipartite houses were predominantly pig farmers, which would give them a specific status within the settlement. Individuals with significant prestige could originate from these houses, as manifested by drilled celts and battle-axes.

\section{The role of Linear Pottery houses in the neoli- thisation process}

The economic as well as social differentiation of the Neolithic houses and the differences between their occupants as interpreted by their social status and prestige lead to yet another conclusion. We have shown that the occupants of Neolithic houses were differentiated by the types of homes in which they lived, their subsistence (as observed in animal bones) and additional activities (as observed in preferences for artefacts and their functional types). This variability was not expected in Neolithic society, which can lead to reasonable assumptions about the different origins of the occupants. According to current theories, farmers with a complete agricultural system would always have occupied three-part houses, while those living in single-part houses would have been descendants of the original hunter-gatherers who joined the aforementioned group in the course of neolithisation and were only just beginning to farm. The remaining, third, group defies all existing theories about prehistoric agriculture. They could have been cattle farmers (e.g., pigs, as documented in Bylany); however, this can also vary from region to region; at a French CCF settlement, these were hunters of wild boars. Further-more, we cannot rule out a connection with totemic animals, which has so far eluded all modern assumptions about the Neolithic.

We assume that families of different origins lived together in one settlement based on the analyses of the distribution of animal bones within the settlement and of the distribution of artefacts between the different types of houses. These results also require a revision of our previous theories about the Neolithic in Bohemia, as well as theories about the entire process of neolithisation in the Danube region. The abundant literature and the discussions that have continued for nearly a hundred years are not in accordance with our results. The integrationist theory comes closest (Bickle, Whittle 2013.5), although it assumes that the late Mesolithic was abruptly replaced by the early Neolithic in a homogeneous clash between two different societies. Opposing colonisation theories are manifested in different variants with the question "... where is the late Mesolithic? ..." (Bogucki 2003.262), since the archaeological visibility of this period has so far been minimal in the Czech Republic.

If we accept the theory that the two societies met in the same places and that their members lived in the same settlements, a number of issues instantly become easier to resolve. The Neolithic, represented in this period by Linear Pottery, was on a certain scale a symbiosis of different socio-economic groups of inhabitants in one given space. They lived next to each other in separate regions with different natural conditions, or in the same micro-regions with different variants of subsistence, or even in the same settlements in neighbouring houses. In such close coexistence, they might have used the same kinds of pottery, and it is therefore impossible to distinguish between the different groups according to the ceramics they used. The theory of cultural evolution in the form of social symbiosis takes its inspiration 
from the field of natural sciences, i.e. biological evolution (Margulis 2008). This idea could be applied almost entirely to the situation of the interactions of hunter-gatherers and farmers, and opens immense possibilities for new interpretations. These varied societies created a new social system, maintaining cultural identity and social solidarity, comparable to the aceramic Neolithic of the Near East before its collapse at the end of the $8^{\text {th }}$ millennium BC (Rollefson, Köhler-Rollefson 1989). Therefore, the Neolithic Linear Pottery culture and the later Stroked Pottery culture did not replace the Mesolithic culture abruptly or at once. The assumption that neolithisation re- presents revolutionary change is the result of our poor knowledge of symbiogenesis in the Neolithic. The periods through which prehistoric society had to pass, at different times in different places, continued for several centuries or longer, and the transition was accompanied by genetic changes in domesticated animals and plants. We are only beginning to ascertain the brand new system created by the sedentation of society. It is obvious that modern terms cannot be used to describe this development, no matter how hard we try to extrapolate our theories about primitive history from our own post-modern society.

\section{References}

Bickle P., Whittle A. (eds.) 2013. The first farmers of Central Europe. Diversity in LBK lifeways. Cardiff Studies in Archaeology. Oxbow Books. Oxford-Oakville.

Bogucki P. 2003. Neolithic Dispersals in Riverine Interior Central Europe. In A. J. Ammerman, P. Biagi (eds.), The Widening Harvest. Archaeological Institute of America. Boston: 249-272.

Boggard A. 2004. Neolithic Farming in Central Europe. An archaeological study of crop husbandry practices. Routledge. London-New York.

Coudart A. 1998. Architecture et société néolithique. L'unité et la variance de la maison danubienne. Maison des sciences de l'Homme. Paris.

Hachem L. 2011. Le site néolithique de Cuiry-lès-Chaudardes - I. De l'analyse de la faune à la structuration sociale. Internationale Archäologie 120. Verlag Marie Leidorf. Rahden/Wesf.

Kovačiková L., Bréhard S., Šumberová R., Balasse M. and Tresset A. 2012. The new insights into the subsistence and early farming from neolithic settlements in Central Europe. The archaeozoological evidence from the Czech Republic. Archaeofauna 21: 71-97.

Lenneis E. 2000. Hausformen der mitteleuropäischen Linearbandkeramik und des balkanischen Frühneolithikums ein Vergleich. In S. Hiller, V. Nikolov (eds.), Karanovo III. Beiträge zum Neolithikum in Südosteuropa. Phoibos. Wien: 383-388.

Margulis L. 2008. Gaia je pěkná bestie. In J. Brockmann (ed.), Třetí kultura. Za hranice vědecké revoluce. Academia. Praha: 124-136.
Modderman P. J. R. 1970. Linearbandkeramik aus Elsloo und Stein. Analecta Praehistorica Leidensia III. Rijksdienst voor het Oudheidkundig Bodemonderzoek. Amersfoort.

1986. On the typology of the houseplans and their European setting. Památky archeologické 77: 383-394.

1988. The Linear Pottery Culture. Diversity in Uniformity. Berichten van de Rijksdients 38: 63-139.

Pavlů I. 2000. Bylany. Life on the Neolithic Site. Institute of Archaeology. Czech Academy of Sciences. ARUP. Praha.

Peške L., Rulf J. and Slavíková J. 1998. Bylany-ekodata. Specifikace nálezů kostí a rostlinných makrozbytků. Bylany Varia 1: 83-118.

Podborský Vl. 2011. Fenomén neolitického domu. Sborník prací Filozofické fakulty Brněnské university M1415: $17-45$.

Rollefson G. O., Köhler-Rollefson I. 1989. The Collapse of early Neolithic Settlements in the Soutern Levant. In I. Herskovitz (ed.), People and Culture in Change. BAR 508. Archaeopress. Oxford: 73-89.

Stäuble H. 2005. Häuser und absolute Datierung der Ältesten Bandkeramik. Dr Rudolf Habelt GmbH. Bonn.

Van de Velde M. 2007. The Bandkeramik settlement. Analecta Praehistorica Leidensia 39: 223-244. 